\title{
Ride Hailing Regulations in Cali, Colombia: Towards Autonomous and Decent Work
}

\author{
Katherine M.A. Reilly ${ }^{1}$ ) and Luis H. Lozano-Paredes ${ }^{2}$ \\ ${ }^{1}$ Simon Fraser University, Vancouver BC, Canada \\ ${ }^{2}$ Universidad Torcuato di Tella, Buenos Aires, Argentina \\ kreilly@sfu.ca
}

\begin{abstract}
In this article we explore the decent work standard developed by Richard Heeks for digital online labour markets and use a review of empirical research about ride-hailing to adapt this framework to the location-based service delivery market. The framework is then tested against an in-depth analysis of informality and precarity in the ride hailing sector in Cali, Colombia. Findings show that location-based platform workers in Cali lack many decent work protections. However, the case study also demonstrates that workers are evolving creative ways to grapple with specific aspects of precarity within the ride-hailing sector. Based on this analysis, we argue that policy analysis and worker innovations need to 'meet in the middle' rather than follow policy recommendations emanating from other jurisdictions. We suggest some specific policy reforms that will be appropriate to the Colombian and Latin American context.
\end{abstract}

Keywords: Decent Work, Platform Economy, Ride Hailing, Colombia

\section{Introduction}

The digital platform economy is rapidly reorganizing the activities of businesses, workers and consumers alike, and policy makers are often forced to introduce policy solutions before the full implications of new business models are realized and understood. In particular, the platform economy offers greater flexibility to workers, and the possibility to 'be your own boss.' However, this informality may worsen or introduce new forms of precarity among workers in ways that are not currently well understood. Indeed, the platform economy challenges definitions of informality and precarity and therefore renders standard policy responses obsolete. Meanwhile, if policy interventions are to be successful, policy makers need to take into consideration workers' adaptations to their rapidly changing context.

With this in mind, this paper applies Heeks' [19] decent work standard for platform labour to the ride hailing sector in Cali Colombia. Since Heeks' standard was designed for online platform labour, we use a literature review to adapt it to the 'location-based service delivery' market, paying particular attention to the ride-hailing sector, which includes Uber, Lyft, 99Taxis or Easy Taxi. The framework is then used to assess informality and precarity in the ride hailing sector in Cali, Colombia. Results show that workers are developing creative solutions to address precarity or improve opportunity 
within the ride-hailing sector. We suggest how Colombian and Latin American policy can take these findings into account to produce appropriate regulatory frameworks.

\section{Emerging Decent Work Standards for the Digital Economy}

The International Labour Organization (ILO) defines decent work as "opportunities for work that is productive and delivers a fair income, security in the workplace and social protection for families, better prospects for personal development and social integration, freedom for people to express their concerns, organize and participate in the decisions that affect their lives and equality of opportunity and treatment for all women and men" [26]. The decent work standard offers a way to assess whether labour arrangements are 'empowering' to workers, and by extension whether the platform economy offers the possibility of empowerment to workers [43].

The platform economy is theorized to offer unequal levels of opportunity to workers [25 p. 18] and it has the potential to create new patterns of exclusion and precarity [34]. We need frameworks to evaluate the impacts on workers, and to provide guidance to policy-makers.

Heeks [19] addresses this gap with his 'Decent Work in the Digital Economy' guidelines. The framework is based on a review of empirical studies of crowd work platforms. Ride-hailing and related services such as food delivery have different dynamics, since they are geographically constrained [14 p. 32]. So, Heeks' model must be adapted to the location-based service delivery market.

Heeks found that potential benefits from crowd work include access to employment opportunities, unbiased or objective inclusion in labour markets, reasonable earnings (often higher than workers would otherwise earn), career development opportunities, greater flexibility, and in some cases reduced costs [19 p. 10].

Ride hailing studies corroborate Heeks' findings about flexibility [ $32 ; 18$ p. 11], access to employment opportunities [28], and overcoming access barriers that exist in established taxi industries [18 p. 6]. This suggests that ride-hailing apps empower workers to be independent contractors. An analysis of the Mexican case found that Uber drivers can earn significantly higher salaries than traditional taxi drivers depending on hours worked, contributions to social security, and patterns of vehicle ownership. 1 Informal taxi work can be made less precarious through the introduction of ride-hailing apps [34 p. 386]. Finally, ride sharing services have been shown to make more efficient use of automobile resources than traditional taxis [8].

Location-based work is not associated, however, with career development opportunities except as it allows workers to take time away from other full time work until something better comes along, or they complete studies [18 p. 12]. Nor does locationbased work reduce the costs of work, however it may be used to supplement income or

${ }^{1}$ https://ingresopasivointeligente.com/cuanto-gana-un-chofer-de-uber-en-mexico/ 
offset the costs of household expenses such as car maintenance.

Heeks organized key challenges according to the ILO's 2013 decent work scheme: 1) working conditions, 2) the employment situation which includes things like the availability of jobs or the possibility for career development, and 3) the overall employment context including laws and policies, or the possibility for collective bargaining.

Working conditions for crowd workers revolve around whether a platform environment enables to them 'win' contracts and complete tasks for fair compensation. Based on this, Heeks divides working conditions into four key issues: the adequacy of compensation, work processes, working hours, and health and safety.

As with crowdworkers, ride hailing workers express concerns about the costs of ride hailing. Compensation may be inadequate to cover costs [50 p. 6] such as driving to pick-up locations, waiting for customers, car insurance, car maintenance or depreciation, as well as cell service [34 p. 387].

The notion of work processes marks a departure from existing ILO decent work standards, which previously spoke of productive work. Platforms position workers as independent contractors, and the idea of "decent work processes" directs our attention to the need for fair conditions in which to operate an independent business. In the ridehailing space drivers complain about the lack of transparency in how computer algorithms assign rides, which makes it difficult to plan business practices [32; 47 p. 3775]. Also, surge pricing obliges drivers to work at peak times of day in order to earn the highest incomes [51 p. 11; 50 p. 6; 34 p. 392] which takes away their autonomy.

Finally, regarding health and safety, studies suggest that workers would need to drive long days to earn a basic income, leading to fatigue [47 p. 3768]. Drivers may also experience feelings of isolation [50 p. 6], or drive late at night or in unsafe neighborhoods [34 p. 384).

The nature of employment concerns employment status, access to employment opportunities, stability and security of work, the potential for career development, discrimination, and dignity or respect at work.

Employment status is key to understanding decent working conditions in the ridehailing sector. While ride hailing platforms legally designate drivers as independent contractors, they set up information systems that treat them like employees [20] or 'dependent contractors' [41]. Also, since many workers in the global south lack the basic language, skills and infrastructure to take these jobs, they are often subcontracted by middle managers or fleet operators [ $28 ; 30$ p. 46-47; $16 ; 45$ p. 169]. Also, the security and stability of ride-hailing work is heavily dependent on the algorithms used to organize the system. Drivers are vulnerable to sudden changes in service offerings, pricing or algorithms, including ratings systems [46].

Career development opportunities are a major consideration in the crowdworking space, but are less relevant in the ride-hailing space. In contrast, discrimination and 
dignity are significant issues in the ride-hailing space. Hua and Ray [23] find that ridehailing features racialized and gendered patterns of work, and authors report on discrimination both through ride-hailing apps [46] and in person [17].

A third category of issues concerns the overall context for employment, including availability of social protections, possibilities for collective bargaining, access to platform governance, and accountability and legal frameworks.

The lack of social protections for drivers is widely discussed, in particular the fact non-employees may lack access to minimum wage, overtime pay, unemployment insurance, health protections and benefits, rights to collective bargaining $[31 ; 50$ p. $6 ; 34$ p. 385]. However, it is important to note that effective social protections are often nonexistent for large segments of the working poor in developing countries. In this context, the question if often more what can be gained from ride-hailing, rather than what is lost.

There is also a general power and information asymmetry between workers and platform owners in the platform economy [47 p. 3761-71], which is made worse by the fact that labour market flexibility downloads risk and insecurity from firms onto workers [34 p. 385). Meanwhile, drivers face challenges with collective bargaining since the network is designed to connect them with gigs, but not each other [2, p. 12]. However, there are many examples of workers organizing to protect their rights, and online discussions about how to do so productively [5].

Overall, Heeks highlights the significance of work processes to labour relations in the platform economy, with implications for levels of worker autonomy, opportunities for worker creativity and entrepreneurialism, and the human rights of workers with regards to surveillance, data ownership and a host of related issues. This issues is common to all workers in the platform economy.

However, because ride-hailing is localized there are some significant differences in in this sector. Health and safety issues are considerably more important to drivers than crowd workers. The barriers to employment are also very different, including access to an automobile. Training is less likely to work as a way to empower workers in this sector of the economy. Finally, because drivers are so directly dependent on their platform system for connecting with customers, knowledge about those work systems, or control over data about public transport, is essential to the empowerment of localized workers, and their ability to make companies accountable.

Based on this, many policies for decent work in the platform economy could apply across the labor spectrum, such as provision of leave and minimum salary. Others would need to cater to a particular sector. For example, specific health and safety guidelines are necessary for drivers, but would be far less relevant to crowd workers. Similarly, training may not be as necessary in the ride-hailing space, and could be replaced with regulations for the onboarding of new workers, but is a significant concern for crowd workers. Finally, the two largest concerns for localized platform workers are the possibility and right to operate with some measure of autonomy within a highlyautomated system, as well as the right to form collectives to organize their work and 
defend their rights.

\section{Decent work standards and Ride Hailing in Cali, Colombia}

In Cali, Colombia labor informality exceeds $48 \%$ of the population so ride hailing offers an important labor outlet. Even though it is deemed illegal by authorities, it is embraced by workers, and protests against the sector have not arisen. This situation has the potential to generate greater precarity among taxi drivers, so analysis of their situation is merited. This section evaluates the choices and circumstances of workers in Cali against the standards proposed by Heeks on the basis of empirical research carried out by Lozano-Paredes in spring 2018. This included a survey of ride-hailing workers (sample of 200 , confidence $95 \%$, margin of error $3.87 \%$, variability $5 \%$ ), and 5 in-depth interviews.

When surveyed about their motivation for taking up ride-hailing, workers indicated that the platform economy offered a quick way to earn extra income $(46 \%)$, or that they did not find another option (33\%). Interviews clarified that this career path requires few qualifications, has a low level of capital risk since the driver maintains ownership of the main business asset (the vehicle), there is no need to pay an association fee, and there is little supervision, so drivers can meet their personal goals on their own schedule. In interviews drivers indicted that ride-hailing offers a means to fulfill immediate economic need, and that they wanted to gain as much as they could in the sector while it was still possible, before legislation was introduced.

On the theme of working conditions, $79 \%$ of surveyed workers indicated that earning justified continuing to engage in ride-hailing. The Colombia minimum wage is COP 781242 per month, (USD 270) and the average take home earnings for platform workers after expenses, is COP 2300000 per month (USD 767). Meanwhile, a poll of taxi drivers conducted by the National Federation of Merchants [13], for the city of Bogotá D.C., determined that, on average, taxi drivers have a monthly income of COP 1725 000, (USD 575) after paying for expenses such as the rental of the vehicle, maintenance, which are on average COP 363200 (USD 121) per month. Only 3\% of surveyed workers reported valuing flexibility as a key motivator for ride-hailing, though flexibility was emphasized more strongly during interviews.

However ride-hailing workers do not comply with national working time directives. In July 2017, the Colombian Labor Code increased the working day from 8 to 10 hours. This allowed employers to schedule 10 hour shifts without exceeding 48 hours per week. However, interviewees reported working an average of 60 hours per week.

Finally, regarding health and safety, drivers need only comply with the minimum standards for car circulation. Colombia has mandatory insurance for car accidents called the Seguro Obligatorio de Accidentes de Tránsito (SOAT). This is a requirement for driving in general, and not specific to platform work. It is included in the cost of a car, and is amortized over the life of the car by ride hailing workers.

On the topic of employment conditions, there did not appear to be any barriers to 
working in the ride hailing sector, and both Uber and Cabify offer training opportunities, including a course in mobile-use for all participating drivers. This is not the case with the local application, WayCali. At the current time, training is business driven, rather than government mandated. Also, both Uber and Cabify offer workers access to a portable work history, reputation ratings and weekly earnings. However this data is not interoperable between the different platforms (no data portability).

All platforms have company policies guaranteeing anti-discrimination and data protection together with privacy for clients and workers. Colombian regulation lags behind the corporate sector in this regard, and even binding regulation regarding data protection [33] has not been applied to Transportation Network Companies. However, there is no space to resolve disputes between workers, platforms and clients.

Dignity and respect at work are difficult to evaluate. There are not currently any regulations in Colombia addressing this issues, but surveyed drivers did indicate that their expectations were fulfilled by working with ride-hailing platforms ( 64.7 indicated they were substantially, and $35.3 \%$ indicated they were entirely fulfilled). Workers did not express complaints regarding poor treatment by clients, and the perception is that platforms offer a good work environment. It may be that workers expect nothing more than a well-performing platform that allows them to turn a profit. In Cali, workers value the autonomy, flexibility and independence offered by ride-hailing, and their perceptions are shaped by this context.

Finally, regarding the employment context, contributions to social security are voluntary in Cali, and only $8 \%$ of surveyed ride-hailing workers made contributions to insurance, sick and/or maternity leave, or a pension plan. Another $45 \%$ reported contributions from previous work. Non-contribution is especially low among those at the beginning of their professional life (88.2\%) and close retirement (50\%). Younger workers do not feel a need to invest in social security, while older workers feel it is too late. Drivers reported that they would prefer not to pay social security, as it cut into their income. Indeed, they saw future formalization of the sector as a threat, and saw the ability to avoid taxes as a benefit of informal work. This reflects findings for the full labour market in Colombia [27].

Colombian regulation does not offer a categorization for platform works, however platform drivers could possibly be qualified as self-employed "independent workers." This might put them under the Occupational Hazard System, which says that contractors who take on employees for more than a month must contribute to the General System of Labor Risks, however this practice is not currently in effect.

Finally, Colombian legal frameworks do not currently contemplate collective negotiation and collective communication between independent workers, and Colombia currently does not offer a national law regarding platform workers' rights. The debate on this subject is currently open and ongoing. This means that drivers within the ride hailing systems currently do not have access to their metadata or any kind of consumer digital asset management or quality control. Meanwhile, since platforms and platform work are technically illegal in Colombia, there are no grounds for companies such as 
Cabify, WayCali or Uber to share their data with national, regional or local governments.

This evaluation shows that Colombian regulations fall well short of the decent work standards for the platform economy. Currently, in the absence of regulations, businesses fulfil some of the standards suggested by Heeks, and workers are not necessarily demanding changes. But the situation does put workers at risk of precarity. The research also shows that there is considerable diversity between workers, with motivations ranging from supplemental income, to entrepreneurial activity [24 pg. 37-38 and 64], to informal labour, and it is important to ensure that decent work standards take this into consideration.

\section{Entrepreneurialism by Workers in the Ride Hailing Sector}

It would be tempting to suggest that policy interventions in Colombia simply fill in the gap between existing conditions and global standards. However, local context needs to be taken into account if policy development, implementation and uptake is to be successful. This section takes a larger look at the ride-hailing sector in Cali, Colombia based on the above mentioned interviews plus ethnographic work carried out by Lozano-Paredes in spring 2018.

This research showed that there is considerable entrepreneurial activity within the ride hailing sector in Cali. In particular, two groups of drivers have emerged that use WhatsApp to build local ride hailing "platforms." One group has about 300 drivers and the other 50. Drivers use these platforms to supplement their work during off peak times for the big platform companies, and, also to address some of the forms of precarity they experience in the ride hailing space.

The groups were created by enterprising ride-hailing drivers. Workers pay a monthly fee to join a dispatch group, which simply delivers dispatches. It neither offers nor demands verification of driver data, there is no need for compliance with mechanical technical norms, there is no accident insurance, nor contributions to social security.

A second WhatsApp group is available to customers where they can post pickup requests. The customer group grows through referrals as well as previous ratings in established platforms such as Uber. This group also includes intermediaries such as security guards and doormen at apartments, hotels and clubs who post requests on passenger's behalf. Administrators pick up these requests and send them out to drivers through the dispatch channel. Intermediaries are paid COP 1000 (USD 0.35) for each ride contracted or COP 75000 (USD 27) for every 50 services contracted. If the service is to the airport, the payment goes up to COP 5000 (USD 1.77) per ride.

As these services have evolved, the larger group has adopted the Zello walkie-talkie app for dispatch, and it has come to be known as Los Sellos. Through this free application groups of up to 2,500 drivers can sustain communication with each other. To access the Zello service drivers must pay a onetime membership fee of COP 100000 (USD 35 ) and a monthly membership fee of COP 40000 (USD 15). Passengers still post their 
requests to the WhatsApp group, but dispatch becomes more fluid.

The cost of a ride is calculated using a free application called Blumeter. Blumeter is an application that allows users to manage rides made outside of the Uber platform. Pricing can reflect Uber's rates, or it can be customized by the driver.

Over time, organizers have introduced groups for local neighborhoods and subburbs. They have also introduced an inter-city service between Cali and Popayán (140 kms away) and Buenaventura $120 \mathrm{~km}$ ). Requests are received on the main network, and the administrator forwards them to the administrator of the area or route network, who assigns the fare to a driver. The intercity routes are also used for packages.

One of the main reasons these emergent WhatsApp networks are successful, is that Uber, Cabify and WayCali face significant challenges with payments collections in Cali. The cost of using a credit card is very high in Colombia, which means that customers are unlikely to use their credit card for small transactions, such as a $\$ 1$ taxi ride. They would much rather pay in cash. In order to accommodate this, the big platform companies have devised cash payment schemes. Each time a driver takes a cash payment, they incur a debt to the platform for the cost of the commission. The next time that a passenger uses a credit card to pay, this debt is paid down.

This creates an incentive for drivers to avoid customers who use credit cards, as well as an incentive to leave the platform if their commission debt becomes too large. Since there is no shared information system between platforms, and no credit history for drivers, drivers can do this with impunity. In addition, drivers can avoid the commissions charged by big platform companies all together if they connect more directly with customers. Altogether, there is a massive incentive for more localized platforms in cities like Cali, and they produce a win-win situation for drivers and customers, who get the same level of service, but at a lower cost to customers and a higher salary for workers.

In these networks, the passengers, drivers and owners of vehicles know that they are immersed in a scheme that offers few guarantees or protections. For example, there is no support for accidents whatsoever. This risk is apparently already calculated by the workers, who report that it is a risk worth taking. They gain higher income this way, and also avoid some of the pitfalls of working with platform companies, such as problems with rate settlement and poor complaint mechanisms between drivers and platforms.

Drivers see these schemes as a means to achieve personal gain, and to grow a micobusiness by acquiring more vehicles, and these forms of entrepreneurialism should not be quashed. These emergent driver-run platforms are more informal than more established platforms like Uber or Cabify. However, through these schemes, workers are finding creative ways to improve their working conditions. For example, drivers, especially female drivers, enjoy the security of knowing that passengers have been vetted by trusted community members such as security guards posted at known buildings. And also, local collaborations can help drivers connect with fares during 'dead hours' when markets are saturated, thereby improving their income. In addition, these local systems 
allow drivers to enhance their service offering through delivery of packages, or carpooling. And of course, these systems reduce the commissions that are paid to foreign firms or local platform companies, which is one of the surest way of putting money in the pockets of low-income earners.

\section{$5 \quad$ Drawing Conclusions}

In the Colombian context, labor regulations were designed for a radically different labor model, and do not guarantee decent conditions for platform workers. From the point of view of current regulations, the majority of platform workers in Colombia would be considered autonomous workers. Colombian legislation for autonomous workers is clearly insufficient to ensure adequate protections. In particular, the social security system was designed for salaried work, suggesting that Colombia requires new flexible forms of social security.

Based on the research presented here, Colombia should consider a new statute of autonomous and decent digital work, which lays out clear obligations for the companies involved, and offers new ways to extend the benefits currently enjoyed by those who have salaried work to workers in more flexible jobs. However, overregulation that reduces or destroys the incentives that produce innovations in cities like Cali should be avoided. In total, new regulation should seek to achieve a minimum from which no one can be lowered, but not a maximum which no one can reach.

The standards for decent work in the platform economy presented in this paper offer a useful starting point. But in consideration of case study results, they need to be adapted for the Colombian context. They should provide certain clear minimums for drivers, such as regulations for accident and liability insurance. But they should not establish maximum's which no one can reach, such as the requirement that all drivers be made formal employees. The concept of "precariousness" and "informality" in Colombia should be revised to 1) recognize as formal those who have temporary or partial contracts and invoice a minimum amount per month, and 2) grant space to workers who voluntarily choose to categorize themselves as entrepreneurs. Rules such as mandatory pension contributions need to be treated with care, because they can place a heavy burden on informal workers as well as spaces of innovation. Similarly, the right to negotiate collective agreements should be balanced with the right of workers to stand outside of those agreements.

Policies to address ride hailing under conditions of informality need to be evaluated in the context of emergent business models that have significant implications for workers' rights and protections. Policy makers need to consider how to balance community innovations with the previously discussed standards of decent work, and policy proposals need to take into consideration not only the situation of workers in "regular" platforms such as Uber and Cabify, but also the entrepreneurial spirit of workers in the emergent WhatsApp and "Sellos" networks. Decent work standards should be designed such that they do not undermine entrepreneurship, while at the same time protecting against new forms of precarity for sub-contracted workers. Especially in emerging and developing 
countries, attention should be fixed on the need to empower workers to be entrepreneurs and/or innovators and therefore to produce the conditions for their own welfare, while also protecting them from the extremes of economic abuses.

\section{References}

1. Anderson, D. N.: Not just a taxi? For-profit ridesharing, driver strategies, and VMT. Transportation, 41(5), 1099-1117 (2014).

2. Bajwa, U., Knorr, L., Ruggiero, E. D., Gastaldo, D., \& Zendel, A.: Towards an understanding of workers' experiences in the global gig economy. Toronto, Canada: Global Migration \& Health Initiative (2018).

3. Bensusán, G.: Nuevas tendencias en el empleo: retos y opciones para las regulaciones y políticas del mercado de trabajo. Santiago, Chile: Comisión Económica para América Latina y el Caribe (CEPAL) (2016).

4. Berger, T., Chen, C., \& Frey, C. B.: Drivers of Disruption? Estimating the Uber Effect. Oxford, UK: Oxford Martin School, University of Oxford, (2017).

5. Campbell, H.: How To Organize A Group Of Uber Drivers (2016). Retrieved July 11, 2018, from https://therideshareguy.com/how-to-organize-a-group-of-uber-drivers/

6. Cañigueral, A.: Can digital sharing economy platforms pull Latin America's informal sector into the mainstream? Yes. Americas Quarterly, Summer (2015).

7. Chen, M., Chevalier, J., Rossi, P., \& Oehlsen, E.: The Value of Flexible Work: Evidence from Uber Drivers. Working Paper 23296. UCLA Anderson School of Management, (2017).

8. Cramer, J., \& Krueger, A.: Disruptive Change in the Taxi Business: The Case of Uber. The American Economic Review, 106(5), 177-182 (2016).

9. Decreto 2297 de 2015, Pub. L. No. 2297/2015, 10 (2015). Retrieved from https://www.mintransporte.gov.co/descargar.php?idFile=13043

10. Departamento Administrativo Nacional de Estadística. MEDICIÓN DE EMPLEO INFORMAL Y SEGURIDAD SOCIAL TRIMESTRE MÓVIL MARZO - MAYO DE 2017 (Technical Bulletin No. COM-030-PD-001-r004).

11. Drahokoupil, J., \& Piasna, A.: Work in the Platform Economy: Beyond Lower Transaction Costs. Intereconomics, 52(6), 335-340 (2017).

12. Esbenshade, J., \& Shifrin, E.: The Leased Among Us: Precarious Work, Local Regulation, and the Taxi Industry. Labor Studies Journal (2018).

13. FENALCO: Situación de los Conductores de Taxis en Bogotá (2016). Retrieved from http://www.fenalcobogota.com.co/images/pdf/TAXIS-v2.pdf

14. Forde, C., Stuart, M., Joyce, S., Oliver, L., Valizade, D., Alberti, G., ... Carson, C.: The Social Protection of Workers in the Platform Economy (p. 128). European Parliament Think Tank (2017).

15. Galperin, H., \& Alarcon, A.: The Future of Work in the Global South. Ottawa, Canada: International Development Research Centre (IDRC) (2017).

16. Geitung, I.: Uber drivers in Cape Town: Working conditions and worker agency in the sharing economy. University of Oslo, Oslo, Norway (2017).

17. Glöss, M., McGregor, M., \& Brown, B.: Designing for Labour: Uber and the On-Demand Mobile Workforce (pp. 1632-1643). ACM Press (2016).

18. Hall, J., \& Krueger, A.: An Analysis of the Labor Market for Uber's Driver-Partners in the United States. Working Paper No. 22843. National Bureau of Economic Research (2016).

19. Heeks, R.: Decent Work and the Digital Gig Economy: A Developing Country Perspective on Employment Impacts and Standards in Online Outsourcing, Crowdwork, etc. Development Informatics Working Paper Series No. 71 Manchester, UK: Centre for Development Informatics, Global Development Institute, SEED University of Manchester (2017).

20. Hernández, C. A., \& Nava, Y.: Subcontratación: relación laboral encubierta. Telos, 14(3), 
$333-345$ (2012).

21. Hou, L.: Destructive sharing economy: A passage from status to contract. Computer Law \& Security Review (2018).

22. Howcroft, D., \& Bergvall-Kåreborn, B.: A Typology of Crowdwork Platforms. Work, Employment and Society (2018).

23. Hua, J., \& Ray, K.: Beyond the precariat: race, gender, and labor in the taxi and Uber economy. Social Identities, 24(2), 271-289 (2018).

24. Ibáñez Pérez, M.: Viabilidad Técnica y Financiera del Servicio de taxis en el Sistema Integrado de Transporte Público. Universidad Nacional de Colombia, Bogotá, Colombia(2012).

25. Ilavarasan, V.: Automation and Workforce in India: 16 Terrible consequences or impossible? In H. Galperin \& A. Alarcon (Eds.), The Future of Work in the Global South (pp. 1623). Ottawa, Canada: International Development Research Centre (IDRC) (2017).

26. ILO. Decent work. Retrieved June 28, 2018, from http://www.ilo.org/global/topics/decentwork/lang--en/index.htm

27. Jassir, I., Guataquí Roa, J., Hartmann Cortés, K., \& Valdés Rocha, J.: El déficit de trabajo decente en Colombia. Borradores de Investigación No. 70.. Facultad de Jurisprudencia, Universidad del Rosario, (2015).

28. Kashyap, R., \& Bhatia, A.: Taxi Drivers and Taxidars: A Case Study of Uber and Ola in Delhi. Journal of Developing Societies, 34(2), 169-194 (2018).

29. Krakovsky, M.: The new jobs. Communications of the ACM, 61(1), 21-23 (2017).

30. Kute, S.: The Sharing Economy in the Global South: Uber's Precarious Labour Force in Johannesburg. University of the Witwatersrand, Johannesburg, South Africa (2017).

31. Ledesma Cespedes, C.: Estudio regional sobre trabajo autónomo y economía informal. Peru: International Labor Organization (2013).

32. Lee, M. K., Kusbit, D., Metsky, E., \& Dabbish, L.: Working with Machines: The Impact of Algorithmic and Data-Driven Management on Human Workers ACM Press (2015).

33. Ley Estatutaria 1581 de 2012 de Colombia Por la cual se dictan disposiciones generales para la protección de datos personales., Pub. L. No. 1581/2012 (2012).

34. Malin, B. J., \& Chandler, C.: Free to Work Anxiously: Splintering Precarity Among Drivers for Uber and Lyft. Communication Culture \& Critique, 10(2), 382-400 (2017).

35. Mercado Gonzales, C. M.: Crodword Offline o Uber Economy y su Impacto en las Relaciones Laborales. Pontificia Universidad Católica del Perú, Lima, Peru (2017).

36. Miguel (no surname provided). ¿Cuánto Gana Un Chofer De Uber En México? (2017). Retrieved July 9, 2018, from https://ingresopasivointeligente.com/cuanto-gana-un-chofer-deuber-en-mexico/

37. Ministerio de Transporte de Colombia. Por el cual se modifica y adiciona el Capítulo 6 del Título 1 de la Parte 2 del Libro 2 del Decreto 1079 de 2015, en relación con la prestación del Servicio Público de Transporte Terrestre Automotor Especial, y se dictan otras disposiciones, Pub. L. No. 431/2017.

38. Nastiti, A.: Worker Unrest and Contentious Labor Practice of Ride-Hailing Services in Indonesia. 2016 Arryman Fellows Papers. Indonesia: Indonesian Scholarship and Research Support Foundation, (2016).

39. Orobio, J. C.: El carpooling es una solución viable para descongestionar el tráfico del sur. Goverment of Cali (2018).

40. Párraga, F. T.: Economía digitalizada y relaciones de trabajo. Revista de derecho social, 76, 59-82 (2016).

41. Pérez, J. Uber y el monopolio de los datos. Universidad de Chile (2016).

42. Ramos, J., Sehnbruch, K., \& Weller, J.: Quality of employment in Latin America: Theory and evidence. International Labour Review, 154(2), 171-194 (2015).

43. Randolph, G., \& Dewan, S.: Skills, social protection and empowerment in the platform economy: A research and policy agenda for the global South. In H. Galperin \& A. Alarcon (Eds.), 
The Future of Work in the Global South. Ottawa, Canada: International Development Research Centre (IDRC).

44. Ravenelle, A. J.: Sharing economy workers: selling, not sharing. Cambridge Journal Of Regions, Economy And Society, 10(2), 281-295 (2017).

45. Romero, Y. H., \& Sosa, R. V. G.: Modelo de gestión del servicio de transporte UBER. ¿Quién pierde y quién gana? Espacios Públicos, 19(47), 157-175 (2016).

46. Rosenblat, A., Levy, K., Barocas, S., \& Hwang, T.: Discriminating Tastes: Uber's Customer Ratings as Vehicles for Workplace Discrimination. Policy \& Internet, 9(3), 256-279 (2017).

47. Rosenblat, A., \& Stark, L. Algorithmic Labor and Information Asymmetries: A Case Study of Uber's Drivers. International Journal of Communication, 10, 3758-3784 (2016).

48.

Sánchez Quiñones, L., \& Zamora, S.: Tribuna: Un estatuto digital para una revolución laboral (2017). Retrieved July 9, 2018, from https://cincodias.elpais.com/cincodias/2017/12/05/legal/1512463452_233355.html

50. Smith, R., \& Leberstein, S.: Rights on Demand: Ensuring Workplace Standards and Worker Security In the On-Demand Economy. National Employment Law Project (NELP) (2015).

51. Todolí i Signes, A.: El Impacto de la "Uber economy" en las relaciones laborales: los efectos de las plataformas virtuales en el contrato de trabajo. IusLabor, 3, 1-25 (2015).

52. Tran, M., \& Sokas, R. K.: The Gig Economy and Contingent Work: An Occupational Health Assessment. Journal of Occupational and Environmental Medicine, 59(4), 63-66 (2017)

53. Vacano, M. V.: "Sharing economy" versus "informal sector": Jakarta's motorbike taxi industry in turmoil. Anuac, 6(2), 97-101 (2017).

54. Wier, M.L: Uber reflects challenges of gig economy. Canadian HR Reporter, 30(18), 1-8 (2017).

55. Williams, R.: Ridesharing and women: Benefits, barriers, and opportunities for progress. Medium (2018, March 6). 